\section{French Assembly to lay down the law}

\section{Parls}

A Discussion document to be presented to the French National Assembly in the spring could, if accepted, lead to significant changes in civil rights laws relating to organ transplants, biomedical research, in vitro fertilization and personal privacy. The draft law, entitled "Life Sciences and Human Rights", has been produced by a working party set up only last December by Michel Rocard, the prime minister.

The proposal would add to existing legislation on civil rights a new definition providing for the first time a right to the "integrity of the human body". The draft article concerned states that nobody may violate a person's right to the integrity of the human body without his or her consent, unless there is a therapeutic emergency in which consent may not be obtainable.

While the same draft article states that organs or human by-products cannot be subject to ownership claims, or to remuneration (in the case of donors), Article 4 of the proposed act endorses the 1976 'Cavaillet Law' of presumed consent. That allows organs to be removed for transplant from any person judged clinically to be dead, unless the person had expressed wishes to the contrary. This article would also make it illegal for minors to donate organs except to siblings, in which case the opinions of three physicians must be given.

The draft proposes amendments to the existing laws on in vitro fertilization (IVF). It prohibits payment for donated sperm or ova and outlaws the practice of surrogacy, stating that an (infertile) woman can have no claim of maternity if a third party should bear a child ostensibly on her behalf. But the husband or concubine of the surrogate may refuse to recognize the child.

It is also proposed to regulate the conservation of supernumerary embryos arising in the practice of IVF. Unwanted embryos would usually be allowed to develop only for five days (14 days with the approval of the national ethics committee) and may not be used for eugenics experiments or in ways that "violate the integrity of the human race".

Frozen embryos would have to be destroyed after five years or if the putative parents should cease to be a couple (through death, divorce or separation). But such embryos could be donated by these parents to another couple.

The proposed law would also redefine the constitution, independence and impartiality of the national committee on ethics. The last of the six draft articles affirms the right of access by epidemiologists to medical files, but also gives patients the right to be informed when the use of personal information is sought and to oppose it if they choose.

\title{
More without job tenure
}

\section{London}

Two British research councils are planning still further to increase the proportions of their researchers on short-term employment contracts. These trends, acknowledged by the Natural Environment Research Council (NERC) and the Agriculture and Food Research Council (AFRC), arise from plans to channel more resources towards universities. But the councils' managements are conscious of the long-term dangers.

Professor John Knill, chairman of NERC, said last week that the open market for scientific manpower in the European Community from 1992 could mean an influx to Britain of foreign scientists seeking research training and an exodus of highly trained researchers looking for permament posts abroad.

Short-term appointments have increased dramatically in recent years. At AFRC, the number on short-term appointments in the council's own institutes has grown from 30 in 1983 to almost 600 now, and is planned to be 850 in 1994 . But the
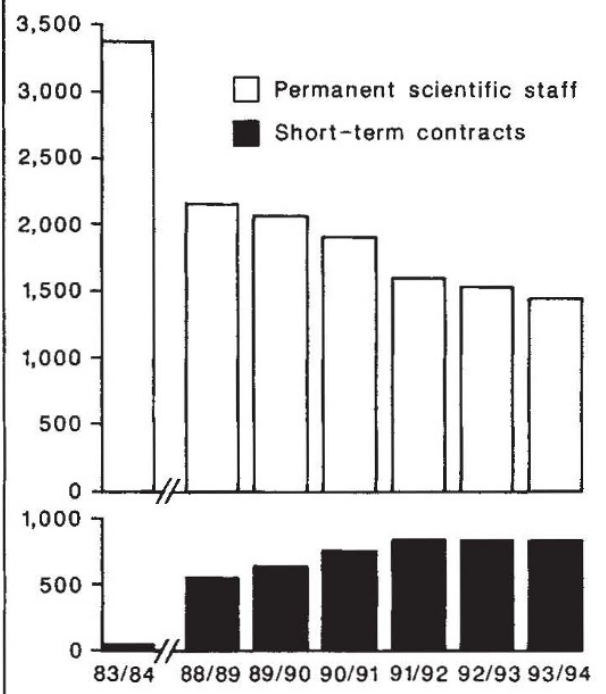

AFRC staff complement - permanent appointments are dwindling.

number of permanent posts will decrease by 700 in the same 5 years and 500 supporting posts will also go.

The trend at NERC is in the same direction, if less swift. Total manpower has decreased by 18 per cent in the past five years (from 3,300 to 2,700 ), but shortterm appointments (both at the council's own institutes and on its university payroll) have increased from 200 to 350 . Both trends will continue. Despite this year's budget increase, NERC expects to have to reduce its staff by 100 a year indefinitely.

Professor Bill Stewart, deputy chairman of AFRC, says that short-term employment contracts will give his council the flexibility to increase the university proportion of its research spending to 30 per cent in the next five years. To help meet industrial demands for skilled manpower, he says AFRC is also planning an extra 200 studentships (for graduate students), mostly in molecular sciences, as well as a number of research fellowships and professorships.

By contrast, NERC's hopes of increasing support for university research seem to rest on the outcome of a request for ax extra $£ 7$ million in its budget for next year, which would be spent on research fellowships and grants. Following the example of the Medical Research Council (see Nature 338, 7; 2 March 1989), AFRC also plans to increase the value of its studentships by $£ 500$ a year from next September. This is an interim measure: all the research councils are now hoping to put into effect an increase of $£ 1,000$ a year in the academic year 1990-91.

Christine McGourty

INDIA'S BUDGET-

\section{Modest science boost}

\section{New Delhi}

SCIENCE does modestly well in the Indian government's election-year budget presented to parliament last week. Seven scientific departments between them will have $\$ 1,460$ million to spend in the financial year beginning on 1 April. That amounts to 2.7 per cent of the total Indian budget and $\$ 150$ million more than last year's support for science and technology.

Predictably for an election year, the budget is orientated towards the poor and unemployed, with less emphasis on expansion of the scientific empire. As in previous years, the Department of Atomic Energy (DAE) gets the lion's share (52.5 per cent) of what there is. The budget for the Department of Space (DoS) has been marginally reduced. On the other hand, 25 per cent more than last year will be spent on biotechnology, chiefly to continue projects for producing biological insecticides against mosquitoes, interferon through genetic engineering and for growing bamboo by tissue culture.

For the first time, India plans to cut its defence expenditure - to $\$ 8,700$ million, a drop of $\$ 130$ million from last year.

The Indian Institute of Science in Bangalore will get $\$ 19$ million for a new supercomputer "for enhancing capacity in virus crystallography and bioengineering". A token provision is also made for the $\$ 160$ million DoS project to develop a cryogenic rocket engine with 12 tonnes of thrust. And the DAE has been granted $\$ 140$ million for a new uranium oxide fuel plant of 50-tonne annual capacity. Notably absent from the budget are funds for projects in materials science.

K.S.Jayaraman 